\title{
Processing and Monthly Summaries of Downscaled Climate Data for Knoxville, Tennessee and Surrounding Region
}

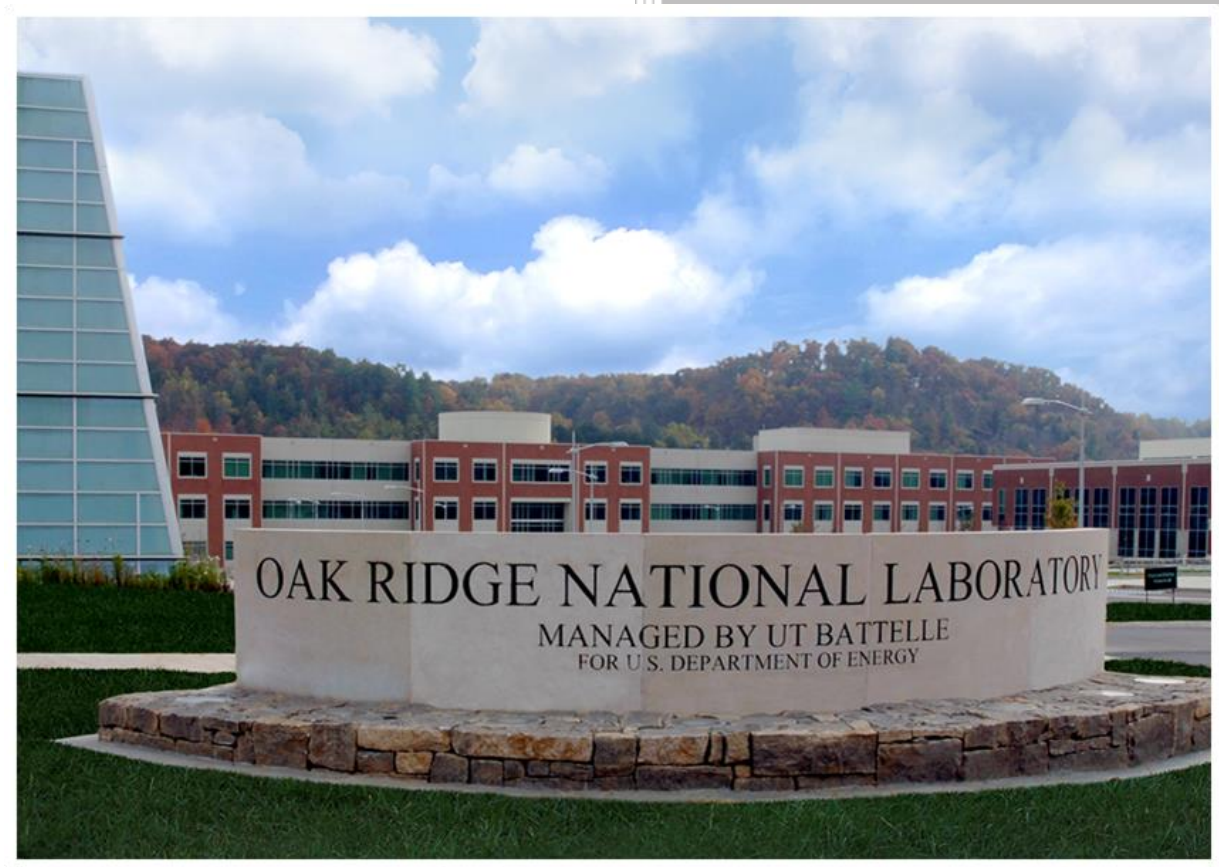

\section{Approved for public release.} Distribution is unlimited.

Linda Sylvester

Olufemi Omitaomu

Esther Parish

Melissa Allen

September 2016 


\title{
DOCUMENT AVAILABILITY
}

Reports produced after January 1, 1996, are generally available free via US Department of Energy (DOE) SciTech Connect.

Website http://www.osti.gov/scitech/

Reports produced before January 1, 1996, may be purchased by members of the public from the following source:

\author{
National Technical Information Service \\ 5285 Port Royal Road \\ Springfield, VA 22161 \\ Telephone 703-605-6000 (1-800-553-6847) \\ TDD 703-487-4639 \\ Fax 703-605-6900 \\ E-mail info@ntis.gov \\ Website http://www.ntis.gov/help/ordermethods.aspx
}

Reports are available to DOE employees, DOE contractors, Energy Technology Data Exchange representatives, and International Nuclear Information System representatives from the following source:

Office of Scientific and Technical Information

PO Box 62

Oak Ridge, TN 37831

Telephone 865-576-8401

Fax 865-576-5728

E-mail reports@osti.gov

Website http://www.osti.gov/contact.html

This report was prepared as an account of work sponsored by an agency of the United States Government. Neither the United States Government nor any agency thereof, nor any of their employees, makes any warranty, express or implied, or assumes any legal liability or responsibility for the accuracy, completeness, or usefulness of any information, apparatus, product, or process disclosed, or represents that its use would not infringe privately owned rights. Reference herein to any specific commercial product, process, or service by trade name, trademark, manufacturer, or otherwise, does not necessarily constitute or imply its endorsement, recommendation, or favoring by the United States Government or any agency thereof. The views and opinions of authors expressed herein do not necessarily state or reflect those of the United States Government or any agency thereof. 
Computational Sciences and Engineering Division Geographic Information Science and Technology Group

Processing and Monthly Summaries of Downscaled Climate Data for Knoxville, Tennessee and Surrounding Region

\author{
Linda Sylvester \\ Olufemi Omitaomu \\ Esther Parish \\ Melissa Allen
}

Date Published:

September 2016

Prepared by

OAK RIDGE NATIONAL LABORATORY

Oak Ridge, TN 37831-6283

managed by

UT-BATTELLE, LLC

for the

US DEPARTMENT OF ENERGY

under contract DE-AC05-00OR22725 



\section{CONTENTS}

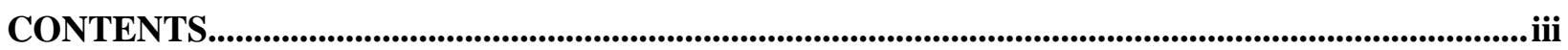

ABSTRACT ..................................................................................................................................................................... 1

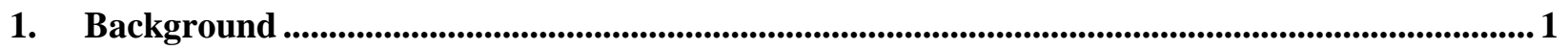

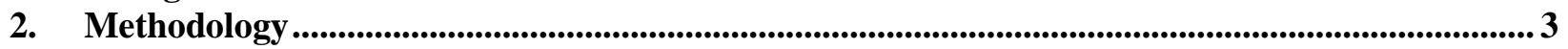

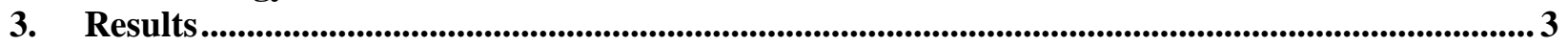

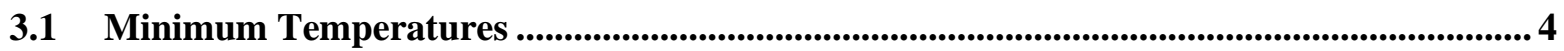

3.2 Maximum Temperatures.................................................................................................................6

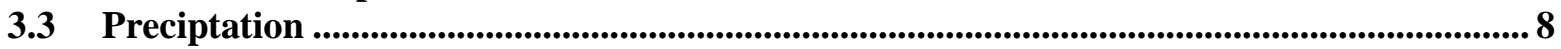

3.4 Past (1980-2005) vs Future (2025-2050) Climate Variables .................................................... 10

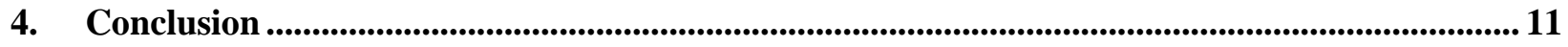

Appendix A. Monthly Summary Values for Each Model, Time Period, and Variable .....................A-2 


\begin{abstract}
Oak Ridge National Laboratory (ORNL) and the City of Knoxville, Tennessee have partnered to work on a Laboratory Directed Research and Development (LDRD) project towards investigating climate change, mitigation, and adaptation measures in mid-sized cities. ORNL has statistically and dynamically downscaled ten Global Climate Models (GCMs) to both $1 \mathrm{~km}$ and $4 \mathrm{~km}$ resolutions. The processing and summary of those ten gridded datasets for use in a web-based tool is described. The summaries of each model are shown individually to assist in determining the similarities and differences between the model scenarios. The variables of minimum and maximum daily temperature and total monthly precipitation are summarized for the area of Knoxville, Tennessee for the periods of 1980-2005 and 2025-2050.
\end{abstract}

\title{
1. BACKGROUND
}

Oak Ridge National Laboratory (ORNL) and the City of Knoxville, Tennessee have partnered to work on a Laboratory Directed Research and Development (LDRD) project towards investigating climate change, mitigation, and adaptation measures in mid-sized cities. Knoxville is particularly interested in knowing future flooding possibilities and the best placement for green infrastructure. Outputs from Global Climate Models (GCMs) are often at a resolution that is too coarse for decision makers to use at a local level. Downscaling the data and the use of bias-correction allow for the information to be scaled to a finer resolution that is more relevant for managing and allocating local resources. ORNL has statistically and dynamically downscaled ten GCMs to both $1 \mathrm{~km}$ and $4 \mathrm{~km}$ resolutions ${ }^{1}$. The processing of those ten gridded datasets for use in a web-based tool, and for general use in GIS platforms, is described in this document. Specifically, the creation of data that are location specific and summarized for use in the area of Knoxville, Tennessee.

The ten climate models (Table 1) were selected based on data availability and to represent one model from each of the Coupled Model Intercomparison Project phase 5 (CMIP5) ${ }^{2}$. The GCM outputs were dynamically downscaled, using Regional Climate Model version 4 (RegCM4), to $18 \mathrm{~km}$. These outputs of daily precipitation and minimum/maximum temperatures were then statistically bias-corrected to $4 \mathrm{~km}$ grid cells using PRISM data ${ }^{3}$. The $18 \mathrm{~km}$ climate data was also re-gridded and bias-corrected using Daymet data ${ }^{4}$ to create the $1 \mathrm{~km}$ data. Netcdf files of the $1 \mathrm{~km}$ and $4 \mathrm{~km}$ datasets were obtained for daily minimum temperature (Tmin), daily maximum temperature (Tmax), and daily precipitation values for the years 1980-2005 and 2025-2050. The $1 \mathrm{~km}$ climate model data was used for creating the monthly summaries for the area surrounding Knoxville, Tennessee.

The original area the acquired netcdf files covered was an area larger than necessary for the purpose of the analysis (Figure 1). Had the initial area been used, the results would have been skewed by the Smoky Mountains to the east and other areas surrounding the actual area of interest for this study. The climate pattern of local information would have been obscured by this extra information. The area of interest is defined not just as the county which the city of Knoxville resides but, more importantly, includes the

\footnotetext{
${ }^{1}$ Methodology described in Ashfaq, M., Bowling, L. C., Cherkauer, K., Pal, J. S., \& Diffenbaugh, N. S. (2010). Influence of climate model biases and daily-scale temperature and precipitation events on hydrological impacts assessment: A case study of the United States. Journal of Geophysical Research, 115(D14). http://doi.org/10.1029/2009JD012965

${ }^{2}$ Further information can be found in Naz, B. S., Kao, S.-C., Ashfaq, M., Rastogi, D., Mei, R., \& Bowling, L. C. (2016). Regional hydrologic response to climate change in the conterminous United States using high-resolution hydroclimate simulations. Global and Planetary Change, 143, 100-117.

http://doi.org/10.1016/j.gloplacha.2016.06.003

${ }^{3} \mathrm{http} / / /$ prism.oregonstate.edu/

${ }^{4} \mathrm{https}: / /$ daymet.ornl.gov/
} 
HUC 12 watersheds (representing the hydrologic unit code of 12 digits) that cover Knox County, Tennessee. By using the watersheds as a boundary, the precipitation that falls within the watersheds affecting Knox County will be accounted for in the climate summary.

Table 1: Brief summary of ten downscaled climate models used to summarize data for the area surrounding Knoxville, Tennessee.

\begin{tabular}{|c|c|c|c|c|c|c|c|c|c|c|}
\hline \multirow[t]{2}{*}{ Model } & \multirow[t]{2}{*}{ Center } & \multicolumn{7}{|c|}{ Model Components } & \multirow{2}{*}{$\begin{array}{l}\text { Atmospheric } \\
\text { Resolution } \\
\text { (degrees) } \\
\text { One degree } 111 \mathrm{~km} \\
\text { at the equator }\end{array}$} & \multirow{2}{*}{$\begin{array}{l}\text { Vertical } \\
\text { levels in } \\
\text { atmosphere }\end{array}$} \\
\hline & & 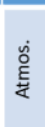 & 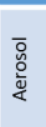 & 宅 & 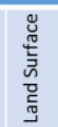 & $\begin{array}{l}\text { ॠ్ } \\
\text { ه̆ }\end{array}$ & 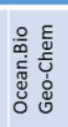 & $\frac{\Xi}{\cong}$ & & \\
\hline ACCESS & $\begin{array}{l}\text { Commonwealth Scientific and Industrial Research } \\
\text { Organization and Bureau of Meteorology, Australia }\end{array}$ & - & • & & • & • & & • & $1.25 \times 1.88$ & 38 \\
\hline BCC-CSM & $\begin{array}{l}\text { Beijing Climate Center, China Meteorological } \\
\text { Administration }\end{array}$ & - & • & & • & • & - & • & $2.79 \times 2.81$ & 26 \\
\hline CCSM4 & National Center for Atmospheric Research, USA & • & • & & • & • & & • & $0.94 \times 1.25$ & 26 \\
\hline CMCC-CM & $\begin{array}{l}\text { Centro Euro-Mediterraneo per I Cambiamenti } \\
\text { Climatici }\end{array}$ & • & • & & & • & & • & $0.75 \times 0.75$ & 31 \\
\hline FGOALS & $\begin{array}{l}\text { LASG, Institute of Atmospheric Physics, } \\
\text { Chinese Academy of Sciences }\end{array}$ & • & • & & • & • & • & • & $1.66 \times 2.81$ & 26 \\
\hline GFDL-ESM2M & $\begin{array}{l}\text { NOAA Geophysical Fluid Dynamics } \\
\text { Laboratory, USA }\end{array}$ & • & • & & • & • & - & - & $2.02 \times 2.5$ & 48 \\
\hline IPSL-CM5A-LR & Institut Pierre Simon Laplace, France & • & • & & • & • & • & • & $1.89 \times 3.75$ & 39 \\
\hline MPI-ESM-MR & Max Planck Institute for Meteorology, Germany & • & • & & • & • & • & • & $1.87 \times 1.88$ & 95 \\
\hline MRI-CGCM3 & Meteorological Research Institute, Japan & • & • & & • & • & & • & $1.12 \times 1.13$ & 48 \\
\hline NorESM1-M & Norwegian Climate Center, Norway & • & • & • & • & • & & • & $1.89 \times 2.5$ & 26 \\
\hline
\end{tabular}

\section{Area of Interest}

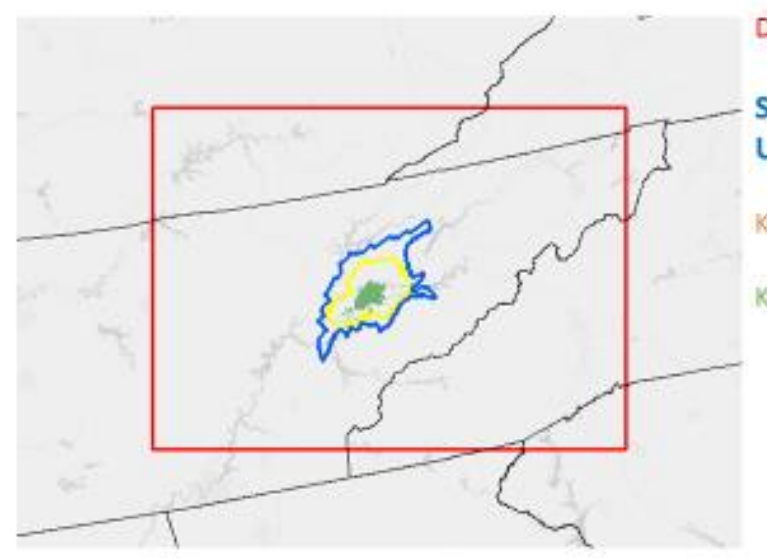

Figure 1: Area of interest for climate model processing for the area surrounding the city of Knoxville, Tennessee. 


\section{METHODOLOGY}

The daily netcdf files, of the original area of coverage, were averaged across each month for each year (1980-2005; 2025-2050) by using cdo commands in a Linux environment. This created a netcdf file for the entire area of coverage that held a monthly average within each grid cell for both past and future time periods of interest. For example, a gridded file for January 1980, February 1980, March 1980... November 2005, December 2005 were created for monthly precipitation totals, precipitation average, Tmin average, and Tmax average. These average monthly netcdf files were projected from Geographic Coordinate System NAD83 to Lambert Conformal Conic WGS84. The resulting geotiffs were clipped to the area of interest, which in this instance, consists of the watersheds that cross the Knox County, Tennessee boundary (Figure 1). RStudio was used to create summaries and graphs from these clipped geotiffs for the specific study area.

\section{RESULTS}

The monthly summary results for both time periods, past (1980-2005) and future (2025-2050), and each of the ten climate models, are summarized and plotted to show the similarities and differences between the models and time periods for each of the climate variables (Tmin, Tmax, and precipitation). Boxplots were created for each of the variables to show the differences between the modeled information in each time period (Figures 2-7). Graphs were also created for each model to show the modeled shift between past and future variables (Figure 8). The information for the summaries is all pertaining to the $1 \mathrm{~km}$ climate data. The monthly summary values for each model, time period, and variable are listed in Appendix A. 


\subsection{MINIMUM TEMPERATURES}

The 1980-2005 downscaled modeled data was bias-corrected, with Daymet, to match historical observations so there will not be much variation. Boxplots of the past average monthly minimum temperature values indicate this (Figure 2), as all the points are clustered on top of one another and the box plot is shown as a single line. There are no outliers.

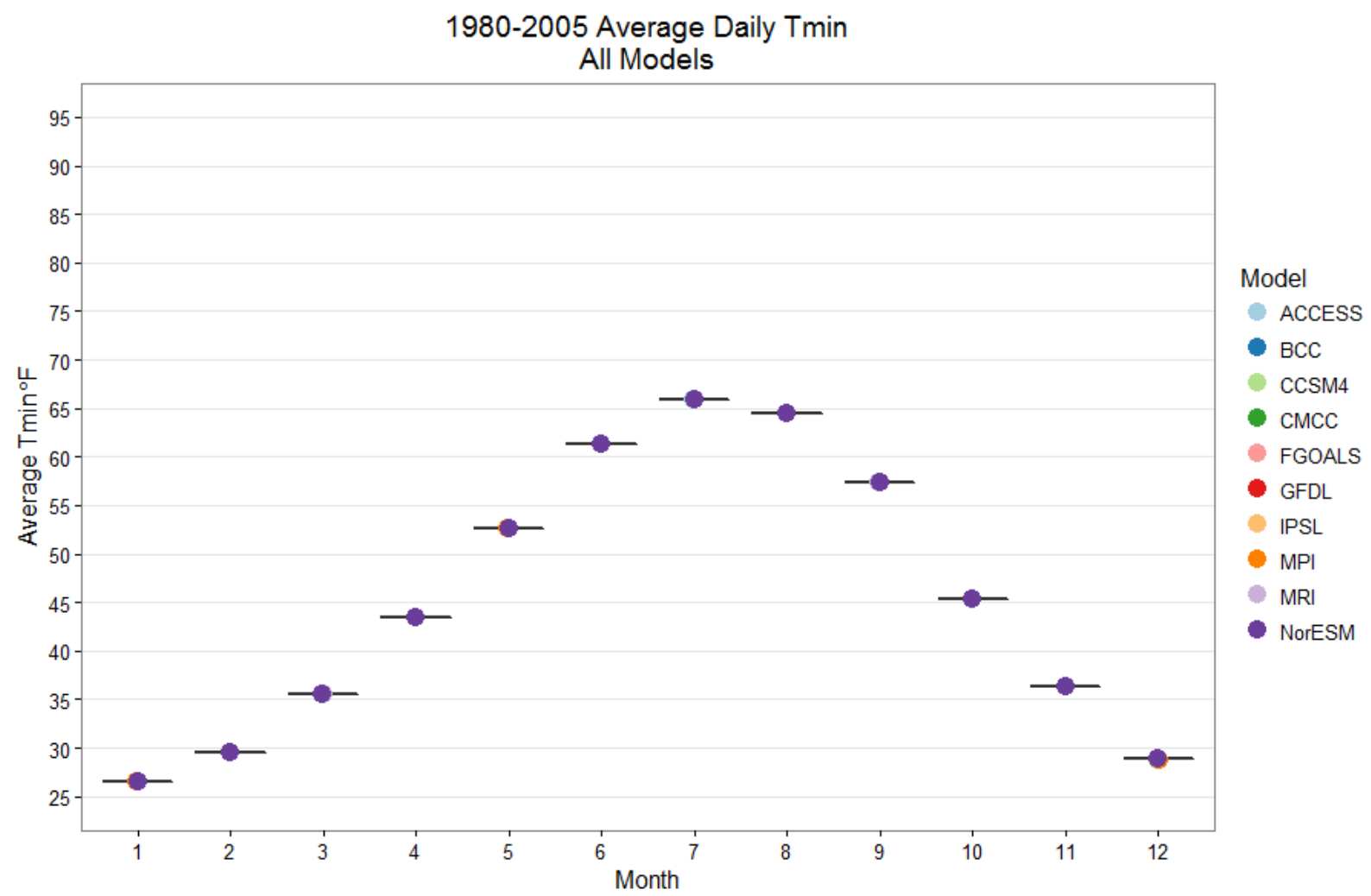

Figure 2: Monthly boxplot summaries of the average daily minimum temperature for ten climate models for the period 1980 2005 for Knoxville, Tennessee area. 
The climate models all begin at the same point for the future time period (2025-2050) but allow for nonstationarity as they calculate possible future scenarios. The future Tmin boxplots (Figure 3) show variation among the average model values. Outliers are labeled with the model name in the month they occur.

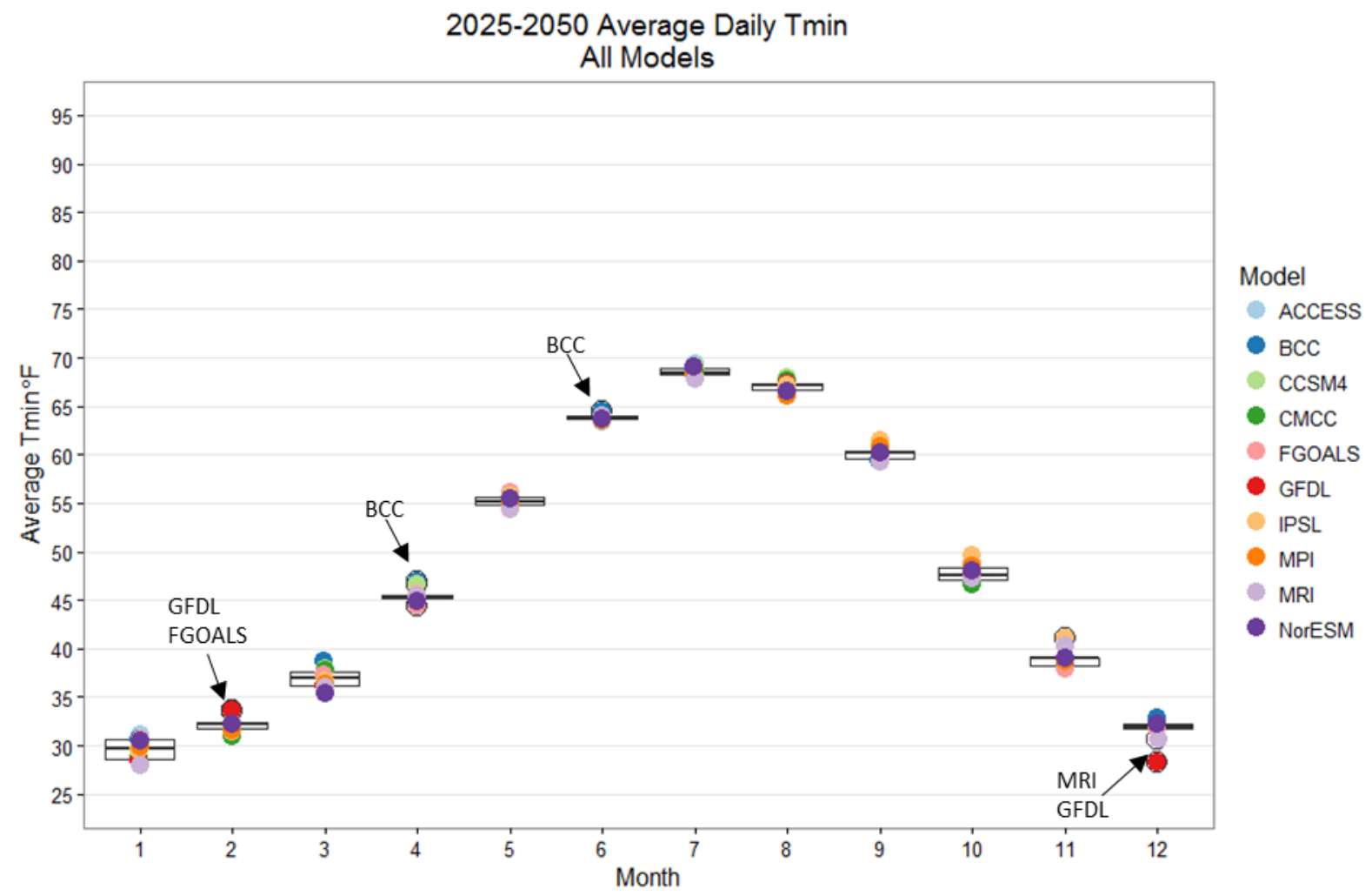

Figure 3: Monthly boxplot summaries of the average daily minimum temperature for the period 2025-2050 for Knoxville, Tennessee area. 


\subsection{MAXIMUM TEMPERATURES}

The 1980-2005 downscaled modeled data was bias-corrected, with Daymet, to match historical observations so there will not be much variation. Boxplots (Figure 4) of the past average monthly maximum temperature values indicate this, as all the points are clustered on top of one another and the box plot is shown as a single line. There are no outliers.

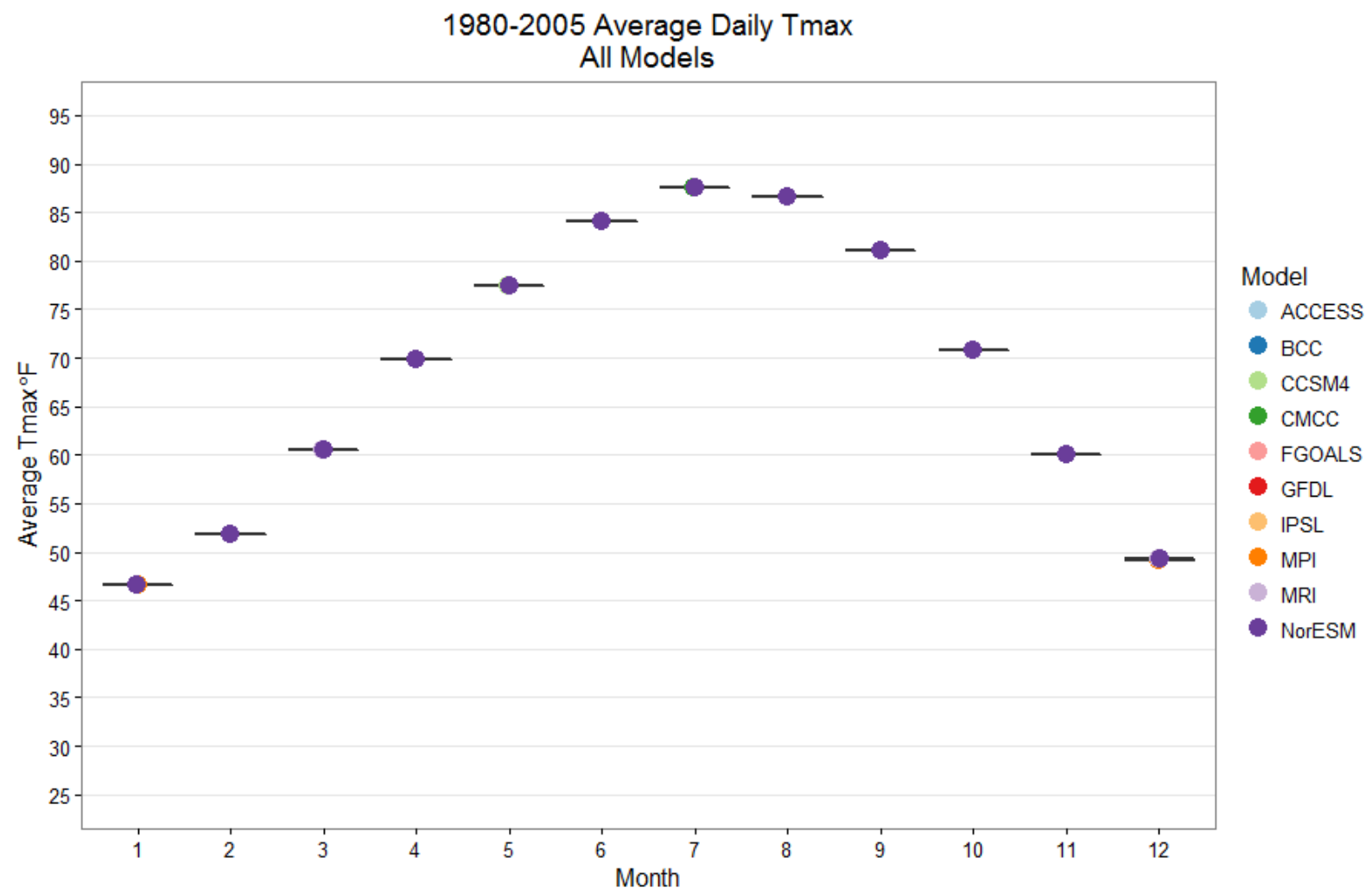

Figure 4: Monthly boxplot summaries of the average daily maximum temperature for ten climate models for the period 1980 2005 for Knoxville, Tennessee area. 
The models all begin at the same point but allow for non-stationarity as they calculate possible future scenarios. The future Tmax boxplot (Figure 5) indicate there is some variation between the models. Outliers are labeled with the model name in the month they occur.

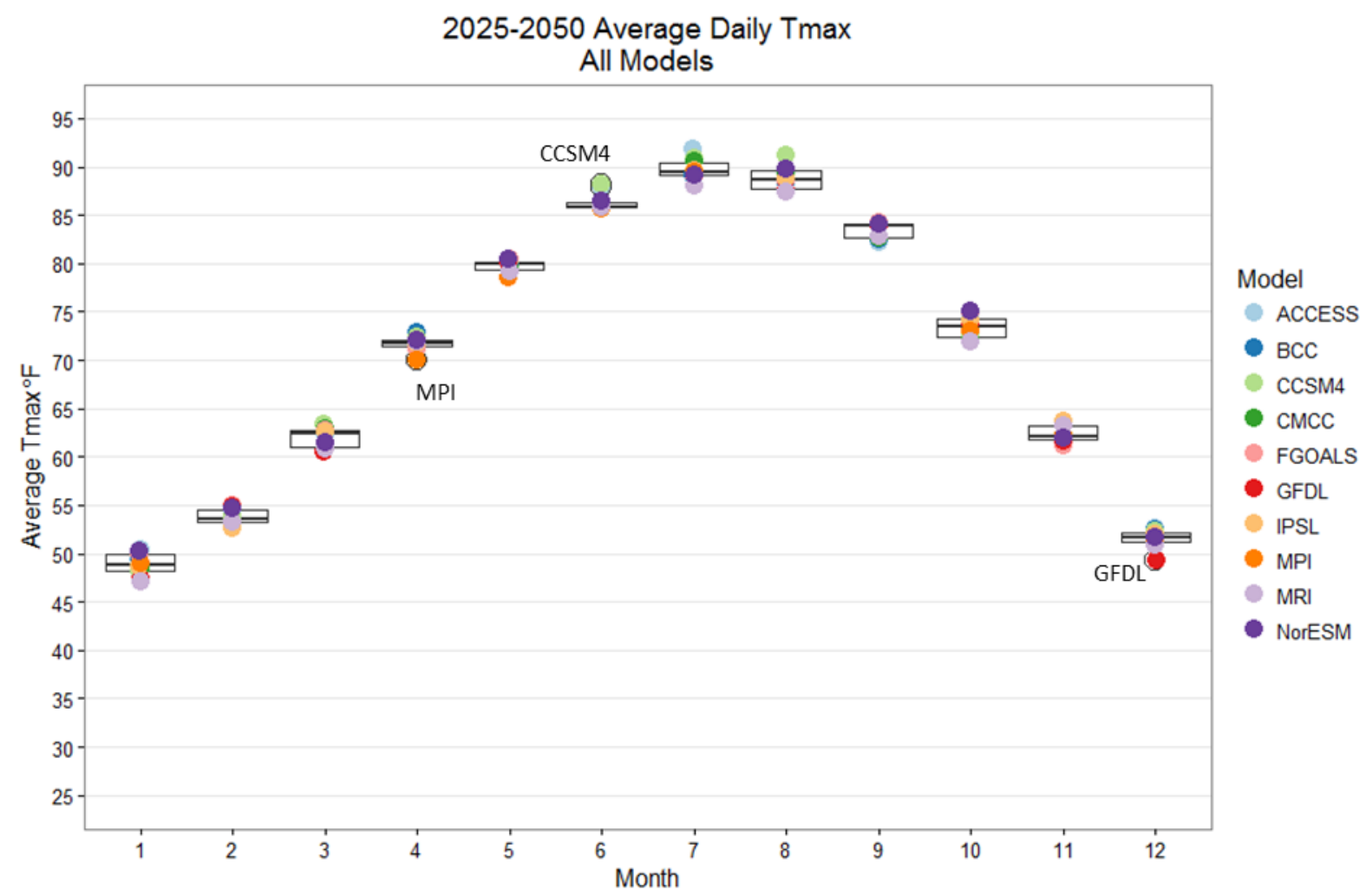

Figure 5: Monthly boxplot summaries of the average daily maximum temperature for ten climate models for the period 2025 2050 for Knoxville, Tennessee area. 


\subsection{PRECIPTATION}

The 1980-2005 downscaled modeled data was bias-corrected, with Daymet, to match historical observations so there will not be much variation. For the precipitation boxplot (Figure 6), the models agree on past monthly precipitation totals, with only December showing some variation among the average monthly totals. There are no outliers.

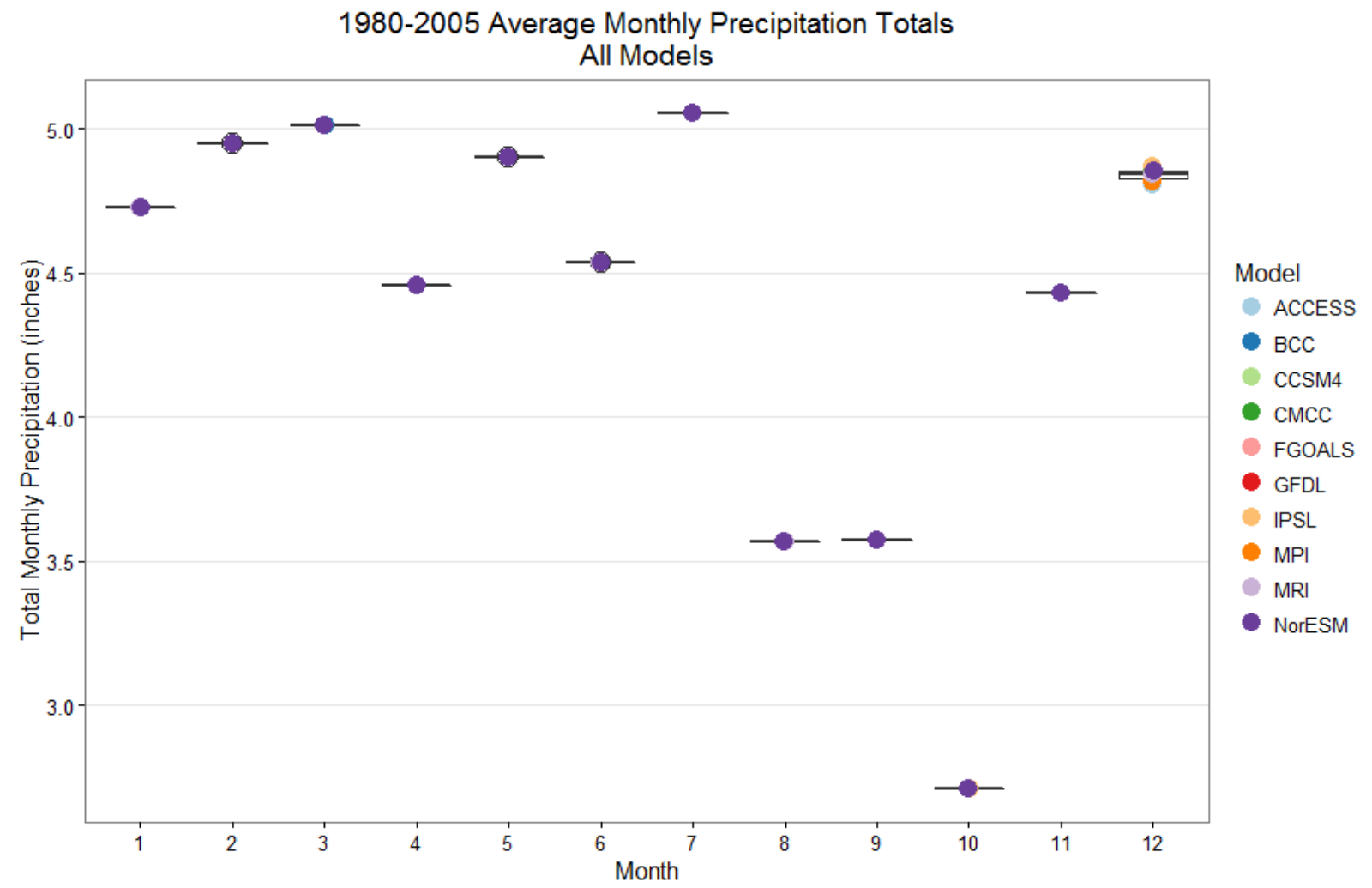

Figure 6: Monthly boxplot summaries of the average monthly precipitation for ten climate models for the period 1980-2005 for Knoxville, Tennessee area. 
The future precipitation models all begin at the same point but allow for non-stationarity as they calculate possible future scenarios. The future precipitation boxplots show variation in the model values with December, again, showing the most variation. Outliers are labeled and indicate which models project higher precipitation values than the other models for that month.

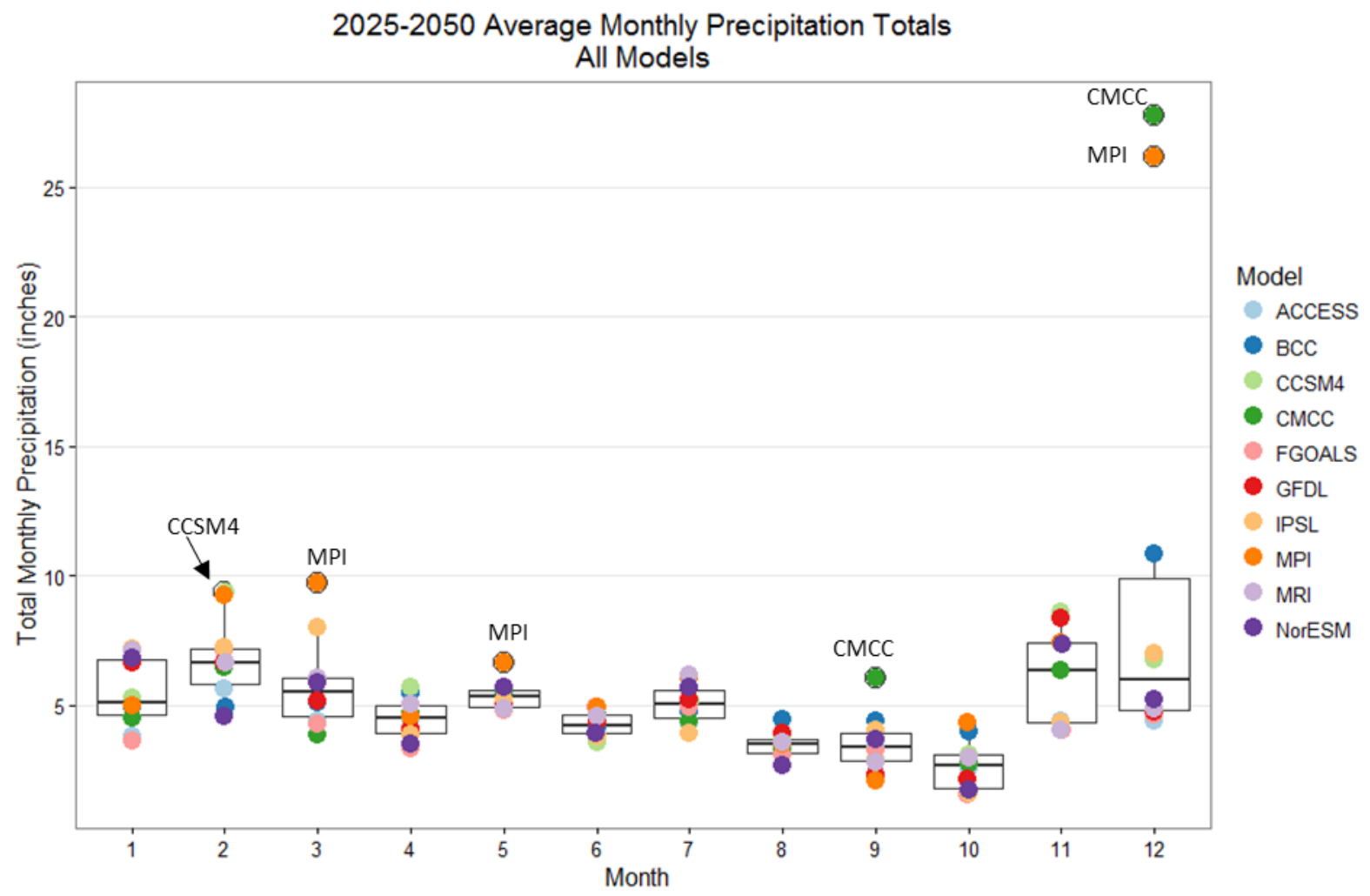

Figure 7: Monthly boxplot summaries of the average monthly precipitation for ten climate models for the period 2025-2050 for Knoxville, Tennessee area. 


\subsection{PAST (1980-2005) VS FUTURE (2025-2050) CLIMATE VARIABLES}

The three climate variables for both past and future periods are shown together to observe shifts in average daily temperatures and average total monthly precipitation (Figure 8). All ten models show an increase in minimum and maximum temperature between the past and future periods. The total monthly precipitation is variable as to whether there is an increase or decrease between the periods with the notable exceptions of the CMCC and MPI models. The future total precipitation values are projected for these models as a very high increase in the amount of December precipitation.

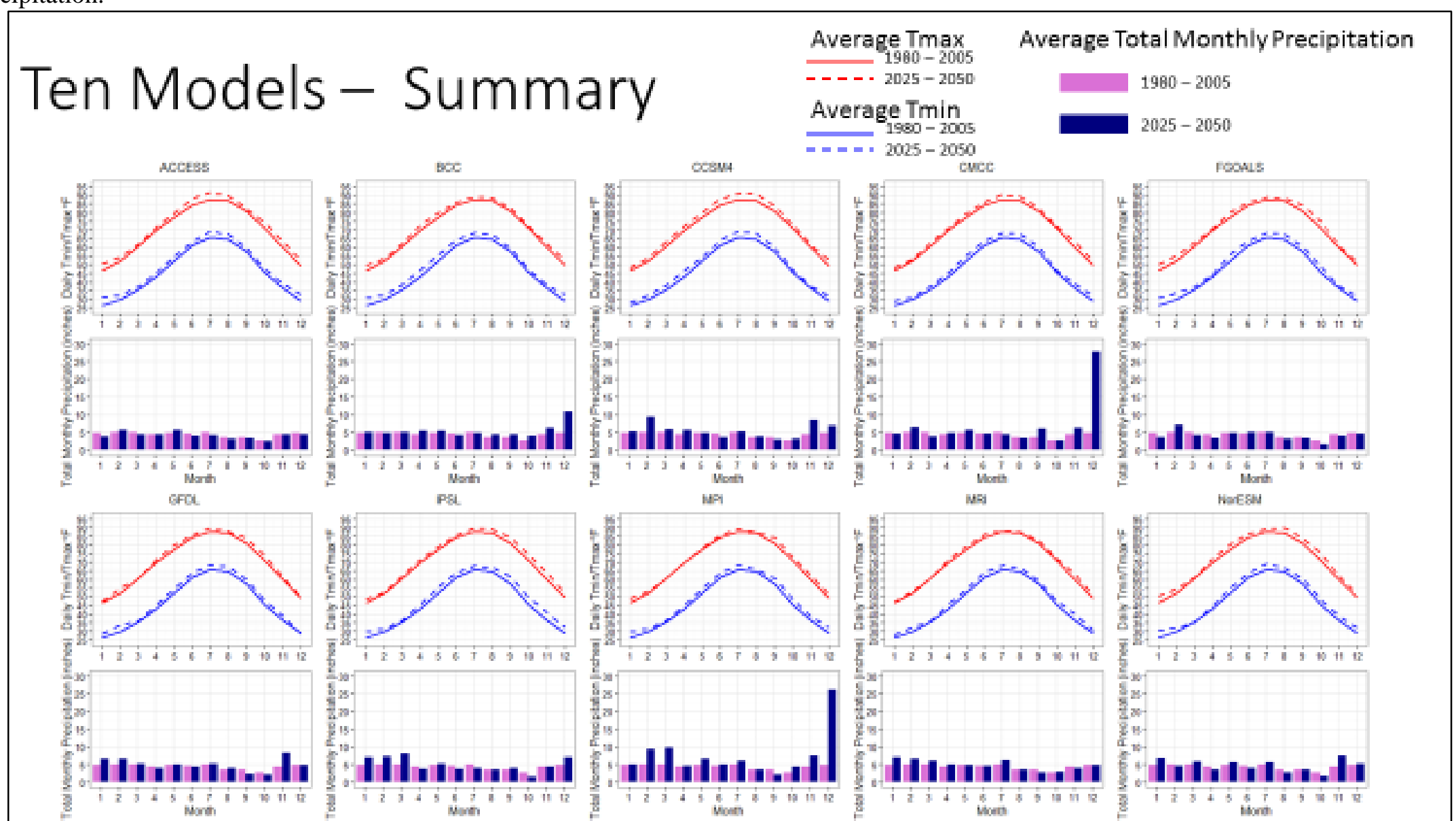

Figure 8: Charts for all ten climate models showing the difference between past (1980-2005) and future (2025-2050) climate variables for the area surrounding Knoxville, Tennessee. 


\section{CONCLUSION}

The ten downscaled GCMs, at the $1 \mathrm{~km}$ grid cell resolution, are processed and summarized for the watersheds that affect Knox County, Tennessee. The overall change in maximum daily temperature is $+2.14^{\circ} \mathrm{F}$, minimum daily temperature is $+2.51^{\circ} \mathrm{F}$, and change in precipitation is +0.88 inches.

Seasonally, the precipitation pattern suggests wetter winters and drier summers. The ten climate model results are shown individually to assist in determining the differences between each of the model scenarios. 
APPENDIX A. Monthly Summary Data Values for Each Model, Time Period, and Variable 


\section{APPENDIX A. Monthly Summary Values for Each Model, Time Period, and Variable}

The values for each month in the periods 1980-2005 and 2025-2050 are listed below. The values are the results of averaging all cells within each geotiff for the study area.

\begin{tabular}{|c|c|c|c|c|c|c|c|c|c|c|c|}
\hline Model & Month & $\begin{array}{l}\text { Total monthly } \\
\text { precip in inches } \\
\text { (present) }\end{array}$ & $\begin{array}{l}\text { Total monthly } \\
\text { precip in inches } \\
\text { (future) }\end{array}$ & $\begin{array}{l}\text { Change in } \\
\text { monthly } \mathrm{p} \\
\text { (inches) }\end{array}$ & $\begin{array}{l}\text { otal } \\
\text { ecip }\end{array}$ & $\begin{array}{l}\text { Tmin in deg F } \\
\text { (present) }\end{array}$ & $\begin{array}{l}\text { Tmin in deg F } \\
\text { (future) }\end{array}$ & $\begin{array}{l}\text { Change in Tmin } \\
\text { (deg F) }\end{array}$ & $\begin{array}{l}\text { Tmax in deg F } \\
\text { (present) }\end{array}$ & $\begin{array}{l}\text { Tmax in deg F } \\
\text { (future) }\end{array}$ & $\begin{array}{l}\text { Change in Tmax } \\
\text { (deg F) }\end{array}$ \\
\hline ACCESS & January & 4.73 & 3.80 & [ & -0.93 & 26.54 & 31.17 & 4.63 & 46.65 & 50.34 & 3.69 \\
\hline ACCESS & February & 4.95 & 5.63 & & 0.68 & 29.56 & 32.21 & 2.65 & 51.87 & 54.00 & 2.13 \\
\hline ACCESS & March & 5.01 & 4.42 & & -0.60 & 35.48 & 37.25 & 1.77 & 60.58 & 62.18 & 1.60 \\
\hline ACCESS & April & 4.46 & 4.47 & & 0.01 & 43.37 & 45.12 & $\square$ & 69.81 & 71.66 & $\square$ \\
\hline ACCESS & May & 4.90 & 5.58 & & 0.68 & 52.59 & 54.89 & 2.30 & 77.46 & 79.90 & 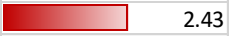 \\
\hline ACCESS & June & 4.53 & 4.00 & $\square$ & -0.53 & 61.36 & 63.40 & $\square$ & 84.15 & 87.85 & 3.70 \\
\hline ACCESS & July & 5.06 & 4.25 & 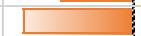 & -0.81 & 65.90 & 69.35 & 3.45 & 87.54 & 91.88 & 4.34 \\
\hline ACCESS & August & 3.57 & 3.14 & $\square$ & -0.43 & 64.50 & 67.39 & 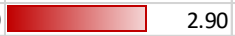 & 86.61 & 89.74 & 3.13 \\
\hline ACCESS & September & 3.57 & 3.44 & 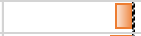 & -0.13 & 57.40 & 59.32 & $\square$ & 81.10 & 82.12 & $\square$ \\
\hline ACCESS & October & 2.71 & 2.55 & 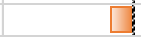 & -0.16 & 45.34 & 47.55 & 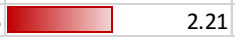 & 70.85 & 74.34 & 3.48 \\
\hline ACCESS & November & 4.43 & 4.42 & & -0.01 & 36.28 & 38.97 & 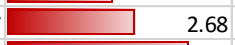 & 60.09 & 63.18 & 3.09 \\
\hline ACCESS & December & 4.81 & 4.40 & $\square$ & -0.41 & 28.84 & 32.63 & 3.80 & 49.13 & 52.58 & 3.46 \\
\hline
\end{tabular}

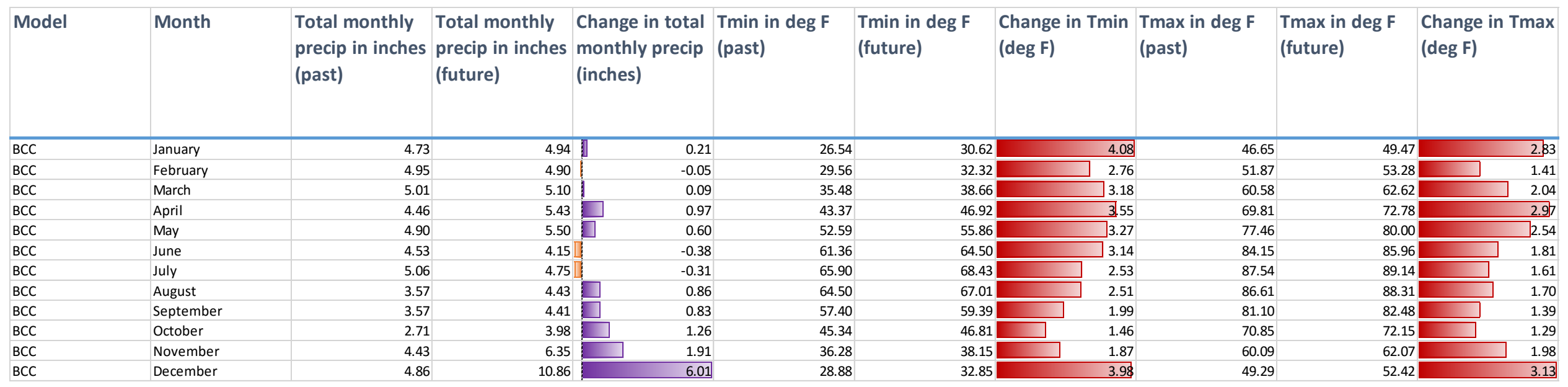




\begin{tabular}{|c|c|c|c|c|c|c|c|c|c|c|c|}
\hline Model & Month & $\begin{array}{l}\text { Total monthly } \\
\text { precip in inches } \\
\text { (past) }\end{array}$ & $\begin{array}{l}\text { Total monthly } \\
\text { precip in inches } \\
\text { (future) }\end{array}$ & $\begin{array}{l}\text { Change in total } \\
\text { monthly precip } \\
\text { (inches) }\end{array}$ & $\begin{array}{l}\text { Tmin in deg F } \\
\text { (past) }\end{array}$ & $\begin{array}{l}\text { Tmin in deg F } \\
\text { (future) }\end{array}$ & $\begin{array}{l}\text { Change in Tmin } \\
\text { (deg F) }\end{array}$ & $\begin{array}{l}\text { Tmax in deg F } \\
\text { (past) }\end{array}$ & $\begin{array}{l}\text { Tmax in deg F } \\
\text { (future) }\end{array}$ & $\begin{array}{l}\text { Change in } 1 \\
\text { (deg F) }\end{array}$ & $\max$ \\
\hline CCSM4 & January & 4.73 & 5.27 & 0.54 & 26.54 & 28.09 & 1.55 & 46.65 & 48.20 & $\square$ & 1.55 \\
\hline CCSM4 & February & 4.95 & 9.38 & 4.43 & 29.56 & 32.33 & 2.77 & 51.87 & 53.81 & 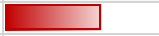 & 1.94 \\
\hline CCSM4 & March & 5.01 & 5.87 & $\square$ & 35.48 & 37.95 & 2.48 & 60.58 & 63.44 & 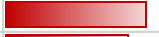 & 2.86 \\
\hline CCSM4 & April & 4.46 & 5.68 & $\square$ & 43.37 & 46.56 & 3.19 & 69.81 & 72.33 & 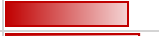 & 2.51 \\
\hline CCSM4 & May & 4.90 & 4.88 & -0.02 & 52.59 & 54.42 & 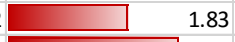 & 77.46 & 80.21 & 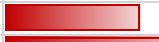 & 2.75 \\
\hline CCSM4 & June & 4.53 & 3.56 & -0.98 & 61.36 & 63.97 & 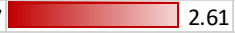 & 84.15 & 88.13 & & 3. 97 \\
\hline CCSM4 & July & 5.06 & 5.19 & 0.13 & 65.90 & 69.08 & 3.17 & 87.54 & 90.94 & & 3.40 \\
\hline CCSM4 & August & 3.57 & 3.72 & 0.15 & 64.50 & 67.90 & 3.40 & 86.61 & 91.13 & & 4.52 \\
\hline CCSM4 & September & 3.57 & 2.92 & -0.66 & 57.40 & 60.10 & 72.70 & 81.10 & 83.93 & 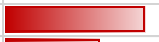 & 2.83 \\
\hline CCSM4 & October & 2.71 & 3.11 & 0.40 & 45.34 & 47.06 & $\square$ & 70.85 & 72.75 & 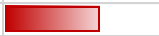 & 1.90 \\
\hline CCSM4 & November & 4.43 & 8.59 & 4.15 & 36.28 & 37.85 & $\square$ & 60.09 & 61.69 & $\square$ & 1.60 \\
\hline CCSM4 & December & 4.82 & 6.77 & 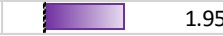 & 28.81 & 31.69 & 2.88 & 49.18 & 52.27 & & 3.09 \\
\hline
\end{tabular}

\begin{tabular}{|c|c|c|c|c|c|c|c|c|c|c|c|}
\hline Model & Month & $\begin{array}{l}\text { Total monthly } \\
\text { precip in inches } \\
\text { (past) }\end{array}$ & $\begin{array}{l}\text { Total monthly } \\
\text { precip in inches } \\
\text { (future) }\end{array}$ & $\begin{array}{l}\text { Change in total } \\
\text { monthly precip } \\
\text { (inches) }\end{array}$ & $\begin{array}{l}\text { Tmin in deg F } \\
\text { (past) }\end{array}$ & $\begin{array}{l}\text { Tmin in deg F } \\
\text { (future) }\end{array}$ & $\begin{array}{l}\text { Change in Tmin } \\
\text { (deg F) }\end{array}$ & $\begin{array}{l}\text { Tmax in deg F } \\
\text { (past) }\end{array}$ & $\begin{array}{l}\text { Tmax in deg F } \\
\text { (future) }\end{array}$ & $\begin{array}{l}\text { Change in } \\
\text { (deg F) }\end{array}$ & $\max$ \\
\hline CMCC & January & 4.73 & 4.53 & -0.20 & 26.54 & 28.75 & 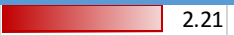 & 46.65 & 48.34 & 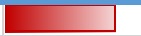 & 1.69 \\
\hline CMCC & February & 4.95 & 6.46 & 1.51 & 29.56 & 31.03 & $\square$ & 51.87 & 52.80 & $\square$ & 0.93 \\
\hline CMCC & March & 5.01 & 3.86 & -1.15 & 35.48 & 37.73 & 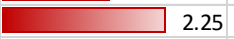 & 60.58 & 62.85 & $\overline{2}$ & 2.26 \\
\hline CMCC & April & 4.46 & 4.72 & 0.26 & 43.37 & 45.41 & 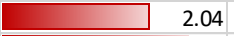 & 69.81 & 71.33 & $\square$ & 1.52 \\
\hline CMCC & June & 4.53 & 4.63 & 0.09 & 61.36 & 63.60 & 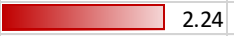 & 84.15 & 85.79 & $\square$ & 1.64 \\
\hline CMCC & July & 5.06 & 4.41 & -0.64 & 65.90 & 68.39 & 2.49 & 87.54 & 90.57 & & 3.03 \\
\hline CMCC & August & 3.57 & 3.28 & -0.28 & 64.50 & 67.56 & 3.07 & 86.61 & 89.26 & 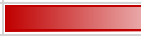 & 2.65 \\
\hline CMCC & September & 3.57 & 6.03 & 2.46 & 57.40 & 60.42 & 3.03 & 81.10 & 82.68 & $\square$ & 1.58 \\
\hline CMCC & October & 2.71 & 2.75 & 0.03 & 45.34 & 46.56 & $\square$ & 70.85 & 72.01 & $\square$ & 1.16 \\
\hline CMCC & November & 4.43 & 6.34 & 1.91 & 36.28 & 39.09 & 2.81 & 60.09 & 63.49 & & 3.40 \\
\hline CMCC & December & 4.85 & 27.78 & 22.93 & 28.84 & 31.78 & 2.95 & 49.27 & 51.57 & 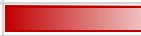 & 2.30 \\
\hline
\end{tabular}




\begin{tabular}{|c|c|c|c|c|c|c|c|c|c|c|}
\hline Model & Month & $\begin{array}{l}\text { Total monthly } \\
\text { precip in inches } \\
\text { (past) }\end{array}$ & $\begin{array}{l}\text { Total monthly } \\
\text { precip in inches } \\
\text { (future) }\end{array}$ & $\begin{array}{l}\text { Change in total } \\
\text { monthly precip } \\
\text { (inches) }\end{array}$ & $\begin{array}{l}\text { Tmin in deg F } \\
\text { (past) }\end{array}$ & $\begin{array}{l}\text { Tmin in deg F } \\
\text { (future) }\end{array}$ & $\begin{array}{l}\text { Change in Tmin } \\
\text { (deg F) }\end{array}$ & $\begin{array}{l}\text { Tmax in deg F } \\
\text { (past) }\end{array}$ & $\begin{array}{l}\text { Tmax in deg F } \\
\text { (future) }\end{array}$ & $\begin{array}{l}\text { Change in Tmax } \\
\text { (deg F) }\end{array}$ \\
\hline FGOALS & January & 4.73 & 3.64 & -1.09 & 26.54 & 30.67 & 4.13 & 46.65 & 49.97 & 3.32 \\
\hline FGOALS & February & 4.95 & 7.11 & 2.16 & 29.56 & 33.48 & 3.92 & 51.87 & 54.92 & 3.04 \\
\hline FGOALS & March & 5.01 & 4.25 & -0.76 & 35.48 & 37.28 & $\square$ & 60.58 & 62.73 & 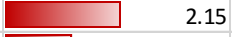 \\
\hline FGOALS & April & 4.46 & 3.31 & -1.15 & 43.37 & 44.47 & $\square$ & 69.81 & 71.04 & $\square$ \\
\hline FGOALS & May & 4.90 & 4.79 & -0.11 & 52.59 & 56.07 & 3.47 & 77.46 & 80.49 & 3.03 \\
\hline FGOALS & June & 4.53 & 4.92 & 0.39 & 61.36 & 63.89 & 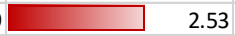 & 84.15 & 86.04 & $\square$ \\
\hline FGOALS & July & 5.06 & 4.94 & -0.12 & 65.90 & 68.34 & 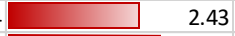 & 87.54 & 89.04 & $\square$ \\
\hline FGOALS & August & 3.57 & 3.08 & -0.49 & 64.50 & 67.35 & 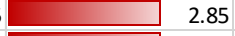 & 86.61 & 88.48 & $\square$ \\
\hline FGOALS & September & 3.57 & 3.29 & -0.28 & 57.40 & 60.25 & 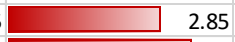 & 81.10 & 84.27 & 3.17 \\
\hline FGOALS & October & 2.71 & 1.57 & -1.14 & 45.34 & 48.75 & 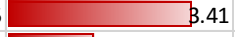 & 70.85 & 74.98 & 4.13 \\
\hline FGOALS & November & 4.43 & 4.03 & -0.40 & 36.28 & 37.87 & $\square$ & 60.09 & 61.20 & $\square$ \\
\hline FGOALS & December & 4.84 & 4.65 & -0.19 & 28.88 & 31.74 & 2.86 & 49.26 & 51.16 & $\square$ \\
\hline
\end{tabular}

\begin{tabular}{|c|c|c|c|c|c|c|c|c|c|c|}
\hline Model & Month & $\begin{array}{l}\text { Total monthly } \\
\text { precip in inches } \\
\text { (past) }\end{array}$ & $\begin{array}{l}\text { Total monthly } \\
\text { precip in inches } \\
\text { (future) }\end{array}$ & $\begin{array}{l}\text { Change in total } \\
\text { monthly precip } \\
\text { (inches) }\end{array}$ & $\begin{array}{l}\text { Tmin in deg F } \\
\text { (past) }\end{array}$ & $\begin{array}{l}\text { Tmin in deg F } \\
\text { (future) }\end{array}$ & $\begin{array}{l}\text { Change in Tmin } \\
\text { (deg F) }\end{array}$ & $\begin{array}{l}\text { Tmax in deg F } \\
\text { (past) }\end{array}$ & $\begin{array}{l}\text { Tmax in deg F } \\
\text { (future) }\end{array}$ & $\begin{array}{l}\text { Change in Tmax } \\
\text { (deg F) }\end{array}$ \\
\hline GFDL & January & 4.73 & 6.64 & 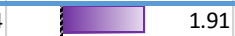 & 26.54 & 28.50 & 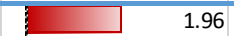 & 46.65 & 47.41 & 0.76 \\
\hline GFDL & February & 4.95 & 6.65 & $\square$ & 29.56 & 33.65 & 4.09 & 51.87 & 54.81 & 2.94 \\
\hline GFDL & March & 5.01 & 5.17 & 0.16 & 35.48 & 36.13 & 0.65 & 60.58 & 60.46 & -0.12 \\
\hline GFDL & April & 4.46 & 4.08 & -0.38 & 43.37 & 45.21 & $\square$ & 69.81 & 71.74 & 1.92 \\
\hline GFDL & June & 4.53 & 4.32 & -0.22 & 61.36 & 63.79 & 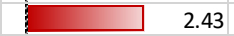 & 84.15 & 85.58 & 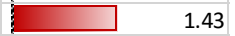 \\
\hline GFDL & July & 5.06 & 5.20 & 0.14 & 65.90 & 68.19 & 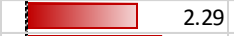 & 87.54 & 89.60 & 2.07 \\
\hline GFDL & August & 3.57 & 3.92 & 0.35 & 64.50 & 67.30 & 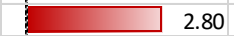 & 86.61 & 87.61 & 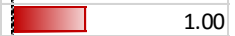 \\
\hline GFDL & September & 3.57 & 2.33 & -1.25 & 57.40 & 59.99 & 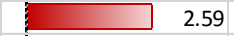 & 81.10 & 83.97 & 2.88 \\
\hline GFDL & October & 2.71 & 2.14 & -0.58 & 45.34 & 47.57 & 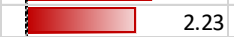 & 70.85 & 73.76 & 2.91 \\
\hline GFDL & November & 4.43 & 8.36 & 3.93 & 36.28 & 38.94 & 2.65 & 60.09 & 61.60 & 1.50 \\
\hline GFDL & December & 4.84 & 4.74 & -0.10 & 28.83 & 28.33 & -0.50 & 49.20 & 49.30 & 0.09 \\
\hline
\end{tabular}




\begin{tabular}{|c|c|c|c|c|c|c|c|c|c|c|c|}
\hline Model & Month & $\begin{array}{l}\text { Total monthly } \\
\text { precip in inches } \\
\text { (past) }\end{array}$ & $\begin{array}{l}\text { Total monthly } \\
\text { precip in inches } \\
\text { (future) }\end{array}$ & $\begin{array}{l}\text { Change in total } \\
\text { monthly precip } \\
\text { (inches) }\end{array}$ & $\begin{array}{l}\text { Tmin in deg F } \\
\text { (past) }\end{array}$ & $\begin{array}{l}\text { Tmin in deg F } \\
\text { (future) }\end{array}$ & $\begin{array}{l}\text { Change in Tmin } \\
\text { (deg F) }\end{array}$ & $\begin{array}{l}\text { Tmax in deg F } \\
\text { (past) }\end{array}$ & $\begin{array}{l}\text { Tmax in deg F } \\
\text { (future) }\end{array}$ & $\begin{array}{l}\text { Change in } \\
\text { (deg F) }\end{array}$ & Tmax \\
\hline IPSL & January & 4.73 & 7.16 & 2.43 & 26.54 & 29.60 & 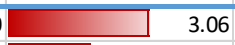 & 46.65 & 48.64 & 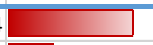 & 1.99 \\
\hline IPSL & February & 4.95 & 7.23 & 2.28 & 29.56 & 31.36 & 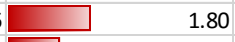 & 51.87 & 52.59 & $\square$ & 0.72 \\
\hline IPSL & March & 5.01 & 7.99 & 2.98 & 35.48 & 36.61 & $\square$ & 60.58 & 62.50 & $\square$ & 1.92 \\
\hline IPSL & April & 4.46 & 3.85 & -0.61 & 43.37 & 45.60 & $\square$ & 69.81 & 71.77 & 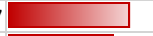 & 1.96 \\
\hline IPSL & May & 4.90 & 5.21 & 0.31 & 52.59 & 55.71 & 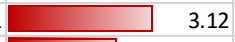 & 77.46 & 79.15 & 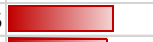 & 1.69 \\
\hline IPSL & June & 4.53 & 3.78 & -0.75 & 61.36 & 63.73 & 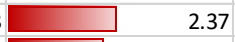 & 84.15 & 85.74 & 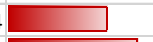 & 1.58 \\
\hline IPSL & July & 5.06 & 3.90 & -1.16 & 65.90 & 67.96 & $\square$ & 87.54 & 89.62 & & 2.08 \\
\hline IPSL & August & 3.57 & 3.50 & -0.07 & 64.50 & 67.16 & 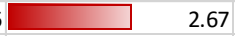 & 86.61 & 88.88 & 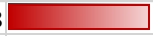 & 2.27 \\
\hline IPSL & September & 3.57 & 4.03 & 0.46 & 57.40 & 61.54 & 4.14 & 81.10 & 84.10 & & $\$ .00$ \\
\hline IPSL & October & 2.71 & 1.60 & -1.11 & 45.34 & 49.59 & 4. 25 & 70.85 & 74.15 & & 3.29 \\
\hline IPSL & November & 4.43 & 4.32 & -0.11 & 36.28 & 41.10 & 4.82 & 60.09 & 63.65 & & 3.56 \\
\hline IPSL & December & 4.87 & 7.01 & 2.14 & 28.88 & 32.18 & 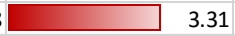 & 49.26 & 51.95 & & 2.69 \\
\hline
\end{tabular}

\begin{tabular}{|c|c|c|c|c|c|c|c|c|c|c|c|}
\hline Model & Month & $\begin{array}{l}\text { Total monthly } \\
\text { precip in inches } \\
\text { (past) }\end{array}$ & $\begin{array}{l}\text { Total monthly } \\
\text { precip in inches } \\
\text { (future) }\end{array}$ & $\begin{array}{l}\text { Change in total } \\
\text { monthly precip } \\
\text { (inches) }\end{array}$ & $\begin{array}{l}\text { Tmin in deg F } \\
\text { (past) }\end{array}$ & $\begin{array}{l}\text { Tmin in deg F } \\
\text { (future) }\end{array}$ & $\begin{array}{l}\text { Change in Tmin } \\
\text { (deg F) }\end{array}$ & $\begin{array}{l}\text { Tmax in deg F } \\
\text { (past) }\end{array}$ & $\begin{array}{l}\text { Tmax in deg F } \\
\text { (future) }\end{array}$ & $\begin{array}{l}\text { Change in } \mathrm{Tr} \\
\text { (deg F) }\end{array}$ & $\max$ \\
\hline MPI & January & 4.73 & 4.97 & 0.25 & 26.54 & 29.84 & 3.30 & 46.65 & 48.95 & 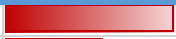 & 2.30 \\
\hline MPI & February & 4.95 & 9.22 & $\square$ & 29.56 & 31.54 & 1.98 & 51.87 & 53.20 & $\square$ & 1.33 \\
\hline MPI & March & 5.01 & 9.72 & $\square$ & 35.48 & 36.38 & $\square$ & 60.58 & 60.78 & $\overline{0}$ & 0.20 \\
\hline MPI & April & 4.46 & 4.56 & 0.10 & 43.37 & 45.39 & 2.02 & 69.81 & 70.04[ & ] & 0.23 \\
\hline MPI & June & 4.53 & 4.95 & 0.42 & 61.36 & 63.59 & 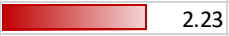 & 84.15 & 85.73 & 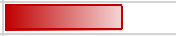 & 1.58 \\
\hline MPI & July & 5.06 & 6.04 & 0.98 & 65.90 & 68.26 & 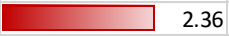 & 87.54 & 89.45 & 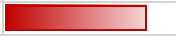 & 1.92 \\
\hline MPI & August & 3.57 & 3.49 & -0.07 & 64.50 & 65.99 & 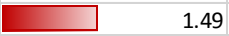 & 86.61 & 87.36 & 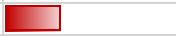 & 0.75 \\
\hline MPI & September & 3.57 & 2.08 & -1.49 & 57.40 & 60.83 & 3.43 & 81.10 & 84.12 & & 3.02 \\
\hline MPI & October & 2.71 & 4.32 & 1.61 & 45.34 & 48.54 & 3.20 & 70.85 & 73.07 & 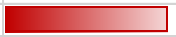 & 2.22 \\
\hline MPI & November & 4.43 & 7.41 & 0 & 36.28 & 38.67 & 2.38 & 60.09 & 62.27 & & 2.17 \\
\hline MPI & December & 4.82 & 26.18 & 21.36 & 28.81 & 32.17 & 3.36 & 49.18 & 51.17 & 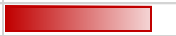 & 1.99 \\
\hline
\end{tabular}




\begin{tabular}{|c|c|c|c|c|c|c|c|c|c|c|c|}
\hline Model & Month & $\begin{array}{l}\text { Total monthly } \\
\text { precip in inches } \\
\text { (past) }\end{array}$ & $\begin{array}{l}\text { Total monthly } \\
\text { precip in inches } \\
\text { (future) }\end{array}$ & $\begin{array}{l}\text { Change in total } \\
\text { monthly precip } \\
\text { (inches) }\end{array}$ & $\begin{array}{l}\text { Tmin in deg } F \\
\text { (past) }\end{array}$ & $\begin{array}{l}\text { Tmin in deg F } \\
\text { (future) }\end{array}$ & $\begin{array}{l}\text { Change in Tmin } \\
\text { (deg F) }\end{array}$ & $\begin{array}{l}\text { Tmax in deg F } \\
\text { (past) }\end{array}$ & $\begin{array}{l}\text { Tmax in deg F } \\
\text { (future) }\end{array}$ & $\begin{array}{l}\text { Change in } 1 \\
\text { (deg F) }\end{array}$ & $\max$ \\
\hline MRI & January & 4.73 & 7.12 & 2.39 & 26.54 & 27.92 & $\square$ & 46.65 & 47.14 & $\square$ & 0.50 \\
\hline MRI & February & 4.95 & 6.67 & 1.72 & 29.56 & 32.16 & 2.60 & 51.87 & 53.27 & & 1.40 \\
\hline MRI & March & 5.01 & 6.07 & 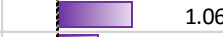 & 35.48 & 36.08 & 0.61 & 60.58 & 60.81 & $\square$ & 0.23 \\
\hline MRI & April & 4.46 & 5.04 & $\square$ & 43.37 & 45.49 & $\square$ & 69.81 & 71.83 & 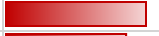 & 2.01 \\
\hline MRI & May & 4.90 & 4.86 & -0.04 & 52.59 & 54.28 & 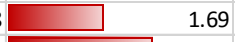 & 77.46 & 79.19 & 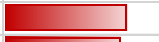 & 1.73 \\
\hline MRI & June & 4.53 & 4.55 & 0.02 & 61.36 & 63.94 & 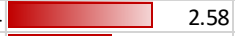 & 84.15 & 85.79 & $\square$ & 1.63 \\
\hline MRI & July & 5.06 & 6.17 & $\square$ & 65.90 & 67.74 & $\square$ & 87.54 & 88.05 & $\square$ & 0.52 \\
\hline MRI & August & 3.57 & 3.56 & -0.01 & 64.50 & 66.51 & $\square$ & 86.61 & 87.33 & $\square$ & 0.73 \\
\hline MRI & September & 3.57 & 2.82 & -0.75 & 57.40 & 59.22 & $\bar{\square}$ & 81.10 & 82.79 & 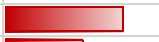 & 1.70 \\
\hline MRI & October & 2.71 & 2.98 & 0.26 & 45.34 & 47.22 & $\square$ & 70.85 & 71.96 & $\square$ & 1.11 \\
\hline MRI & November & 4.43 & 4.06 & -0.37 & 36.28 & 40.24 & 3.96 & 60.09 & 63.25 & & 3.16 \\
\hline MRI & December & 4.84 & 4.89 & 0.05 & 28.86 & 30.67 & $\square$ & 49.22 & 50.90 & 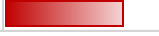 & 1.68 \\
\hline
\end{tabular}

\begin{tabular}{|c|c|c|c|c|c|c|c|c|c|c|}
\hline Model & Month & $\begin{array}{l}\text { Total monthly } \\
\text { precip in inches } \\
\text { (past) }\end{array}$ & $\begin{array}{l}\text { Total monthly } \\
\text { precip in inches } \\
\text { (future) }\end{array}$ & $\begin{array}{l}\text { Change in total } \\
\text { monthly precip } \\
\text { (inches) }\end{array}$ & $\begin{array}{l}\text { Tmin in deg F } \\
\text { (past) }\end{array}$ & $\begin{array}{l}\text { Tmin in deg F } \\
\text { (future) }\end{array}$ & $\begin{array}{l}\text { Change in Tmin } \\
\text { (deg F) }\end{array}$ & $\begin{array}{l}\text { Tmax in deg F } \\
\text { (past) }\end{array}$ & $\begin{array}{l}\text { Tmax in deg F } \\
\text { (future) }\end{array}$ & $\begin{array}{l}\text { Change in Tmax } \\
\text { (deg F) }\end{array}$ \\
\hline NorESM & January & 4.73 & 6.84 & 2.11 & 26.54 & 30.42 & 3.88 & 46.65 & 50.18 & 3.53 \\
\hline NorESM & February & 4.95 & 4.59 & -0.36 & 29.56 & 32.24 & 2.68 & 51.87 & 54.66 & 2.78 \\
\hline NorESM & March & 5.01 & 5.89 & 0.87 & 35.48 & 35.41 & -0.07 & 60.58 & 61.40 & $\square$ \\
\hline NorESM & April & 4.46 & 3.50 & -0.96 & 43.37 & 44.90 & 1.53 & 69.81 & 72.06 & 5 \\
\hline NorESM & June & 4.53 & 3.90 & -0.64 & 61.36 & 63.75 & 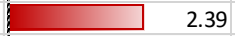 & 84.15 & 86.45 & 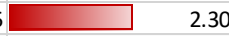 \\
\hline NorESM & July & 5.06 & 5.70 & 0.64 & 65.90 & 69.04 & 3.13 & 87.54 & 89.20 & 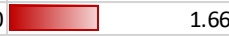 \\
\hline NorESM & August & 3.57 & 2.67 & -0.90 & 64.50 & 66.57 & 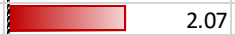 & 86.61 & 89.77 & 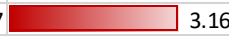 \\
\hline NorESM & September & 3.57 & 3.66 & 0.09 & 57.40 & 60.20 & 2.80 & 81.10 & 84.00 & 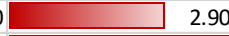 \\
\hline NorESM & October & 2.71 & 1.71 & -1.00 & 45.34 & 48.04 & 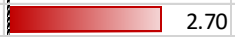 & 70.85 & 75.01 & 4.15 \\
\hline NorESM & November & 4.43 & 7.38 & 2.94 & 36.28 & 39.07 & 2.79 & 60.09 & 61.94 & $+\square$ \\
\hline NorESM & December & 4.85 & 5.20 & 0.34 & 28.84 & 32.25 & 3,41 & 49.27 & 51.64 & 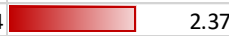 \\
\hline
\end{tabular}

